\title{
ANALISIS KEMAMPUAN PEMECAHAN MASALAH MATEMATIS DAN SELF-EFFICACY SISWA PADA PEMBELAJARAN PROBLEM BASED LEARNING
}

\author{
Rosmawaty Simatupang ${ }^{1}$, Elvis Napitupulu ${ }^{2}$, Asmin $^{2}$
}

\begin{abstract}
ABSTRAK
Penelitian ini bertujuan untuk menganalisis dan mengetahui: (1) tingkat kemampuan pemecahan masalah matematis siswa setelah pembelajaran problem-based learning, (2) kesalahan yang dilakukan siswa dalam menyelesaikan soal pemecahan masalah matematis setelah pembelajaran problem-based learning, (3) self-efficacay siswa pada pembelajaran problem-based learning. Adapun hasil penelitian sebagai berikut: (1) Kategori penilaian siswa berdasarkan tingkat kemampuan pemecahan masalah matematis dari tertinggi ke terendah secara berurutan: kemampuan tinggi 8 orang, sedang 20 orang, dan rendah 10 orang. (2) Kesalahan yang dilakukan siswa dalam menyelesaikan soal pemecahan masalah adalah siswa berkemampuan tinggi 1 orang melakukan kesalahan pada tahap melaksanakan rencana dan 3 orang salah pada tahap memeriksa kembali. Siswa berkemampuan sedang melakukan kesalahan pada tahap membuat rencana sebesar 7 orang, pada tahap melaksanakan rencana 11 orang dan tahap memeriksa kembali sebesar 20 orang. Siswa berkemampuan rendah melakukan kesalahan pada tahap membuat rencana sebesar 10 orang, pada tahap melaksanakan rencana 10 orang dan tahap memeriksa kembali sebesar 10 orang. (3) Selfefficacy siswa berdasarkan dimensi Magnitude dengan tingkat self-efficacy sangat tinggi sebanyak 1 orang, tingkat tinggi sebanyak 2 orang, tingkat sedang sebanyak 5 orang dan tingkat rendah seanyak 5 orang. Dimensi Streanght dengan tingkat self-efficacy tinggi sebanyak 3 orang, tingkat sedang sebanyak 8 orang, dan tingkat rendah sebanyak 6 orang. Dimensi Generality dengan tingkat self-efficacy sangat tinggi sebanyak 2 orang, tingkat tinggi sebanyak 2 orang, tingkat sedang sebanyak 3orang, dan tingkat rendah sebanyak 1 orang.
\end{abstract}

Kata Kunci: analisis, kemampuan pemecahan masalah matematis, self-efficacy, problem- based learning

\section{PENDAHULUAN}

Matematika merupakan ilmu universal yang mendasari perkembangan modern dan mempunyai peran penting dalam berbagai disiplin dan memajukan daya pikir manusia. Hal ini diperkuat Depdiknas (2006) bahwa matematika merupakan salah satu disiplin ilmu yang mendasari perkembangan teknologi modern, karena matematika mempunyai peranan penting dalam berbagai disiplin ilmu lain dan mempunyai pengaruh besar dalam memajukan daya pikir manusia. Perkembangan teknologi modern tidak terlepas dari landasan perkembangan matematika di bidang teori bilangan, aljabar, analisis, teori peluang dan matematika diskrit. Matematika merupakan salah satu mata pelajaran yang mempunyai peran penting dalam dunia pendidikan. Hal ini sesuai dengan Undang-undang No.20 Tahun 2003 pasal 37 secara spesifik menekankan matematika menjadi mata pelajaran wajib di setiap jenjang pendidikan dari tingkat sekolah dasar sampai perguruan tinggi. Pada proses pembelajaran di sekolah, matematika merupakan salah satu mata pelajaran yang memiliki waktu jam pembelajaran yang lebih banyak

${ }^{1}$ Corresponding Author: Rosmawaty Simatupang

Program Magister Pendidikan Matematika, Universitas Negeri

Medan, Medan, 20221, Indonesia

E-mail: rosmawaty06@gmail.com

${ }^{2}$ Co-Author: Elvis Napitupulu \& Asmin

Program Studi Pendidikan Matematika, Universitas Negeri Medan, Medan, 20221, Indonesia dibandingkan pelajaran lain.

Tujuan pembelajaran matematika menurut Kurikulum 2013 (Kemendikbud, 2013) adalah (1) meningkatkan kemampuan intelektual, khususnya kemampuan tingkat tinggi siswa, (2) membentuk kemampuan siswa dalam menyelesaikan suatu masalah secara sistematik, (3) memperoleh hasil belajar yang tinggi, (4) melatih siswa dalam mengomunikasikan ideide, khususnya dalam menulis karya ilmiah, dan (5) mengembangkan karakter siswa. National Council of Teacher of Mathematics (NCTM, 2000), menyatakan bahwa standar matematika sekolah meliputi standar isi (mathematical content) dan standar proses (mathematical processes). Menurut NCTM, standar isi yaitu : (1) bilangan dan operasinya; (2) aljabar; (3) geometri; (4) pengukuran; (5) analisis data dan probabilitas. Adapun standar proses menurut NCTM meliputi: (1) pemecahan masalah matematika (mathematical problem solving); (2) penalaran dan pembuktian matematika (mathematical reasoning and proof); (3) komunikasi matematika (mathematical communication); (4) koneksi matematika (mathematical connection); (5) representasi matematika (mathematical representation). Dimana standar proses tersebut merupakan keterampilan dan pemahaman dasar yang dibutuhkan siswa pada abad ke-21.

Belle (1981) berpendapat bahwa matematika dapat digunakan untuk menyusun pemikiran yang jelas, teliti, tepat dan taat asas (konsisten) melalui latihan menyelesaikan masalah-masalah yang bersifat 
pedagogik. Masalah terjadi karena adanya kesenjangan antara apa yang diharapkan dengan kenyataan, antara apa yang dimiliki dengan apa yang dibutuhkan, atau antara apa yang telah diketahui dengan apa yang ingin diketahui. Dalam pembelajaran matematika, masalah adalah suatu persoalan atau pertanyaan yang bersifat menantang yang tidak dapat diselesaikan dengan prosedur rutin yang sudah biasa dilakukan atau sudah diketahui. Hal tersebut sesuai dengan pendapat Muhardhikawati, Mardiyana, dan Setiawan (2017) yang menyatakan suatu soal disebut masalah bagi seorang siswa, jika: (1) pertanyaan yang dihadapkan dapat dimengerti oleh siswa, namun pertanyaan itu harus merupakan tantangan baginya untuk menjawab, dan (2) pertanyaan tersebut tidak dapat dijawab dengan prosedur rutin yang telah diketahui oleh siswa.

Berdasarkan hal di atas, salah satu kemampuan matematika yang harus dimiliki oleh siswa dalam pembelajaran adalah kemampuan pemecahan masalah. Hal ini sesuai dengan teori belajar yang dikemukakan Gagne (1970) bahwa keterampilan intelektual tingkat tinggi dapat dikembangkan melalui pemecahan masalah. Pemecahan masalah merupakan tipe belajar paling tinggi dari delapan tipe yang dikemukakan Gagne, yaitu: signal learning, stimulus-response learning, chaining, verbal association, discrimination learning, concept learning, rule learning, dan problem solving.

Muhardhikawati, Mardiyana, dan Setiawan (2017) juga berpendapat kemampuan pemecahan masalah matematis penting dimiliki oleh siswa, karena: (1) Kemampuan pemecahan masalah sebagai salah satu hasil dari pembelajaran matematika yang harus dimiliki oleh siswa, sehingga diharapkan siswa menjadi individu yang mampu menyelesaikan masalah yang dihadapinya sendiri. (2) Kemampuan pemecahan masalah sebagai salah satu komponen proses yang melibatkan siswa dalam memahamkan matematika. (3) Keterampilan dan pengetahuan pemecahan masalah nantinya akan digunakan dan diaplikasikan didalam kehidupan nyata dalam menghadapi masalah apapun. Berdasarkan pendapat ahli dan hasil penelitian di atas dapat disimpulkan bahwa kemampuan pemecahan masalah matematis perlu dimiliki siswa dan dilatih, sehingga apabila siswa terbiasa memecahkan masalah matematika maka akan mampu mengambil keputusan secara tepat dengan penuh pertimbangan.

Kemampuan pemecahan masalah matematis menurut Hasratuddin (2018) adalah kemampuan untuk mengatasi kesulitan bermatematika dengan menggabungkan konsep-konsep dan aturan-aturan matematika yang telah diperoleh sebelumnya untuk mencapai tujuan yang diinginkan. Pemecahan masalah yang baik adalah pemecahan masalah yang bukan sekedar melihat hasil akhir, tetapi lebih mengutamakan proses atau tahap-tahap yang digunakan dalam menyelesaikan sebuah permasalahan. Menurut Polya (1973), tahap-tahap kemampuan pemecahan masalah matematis meliputi: (1) Memahami masalah/membaca masalah (understand the problem/ read the problem); (2) Menyusun rencana/memilih strategi (devise a plan/select a strategy); (3) Melaksanakan rencana/memecahkan masalah (carry out a plan/ solve the problem); dan (4) Memeriksa kembali (look back) . Siswa yang dapat menerapkan keempat tahap-tahap tersebut akan mencapai proses belajar yang baik sehingga memberikan hasil belajar yang baik.

Berdasarkan hasil studi PISA tahun 2012 (OECD, 2013) Indonesia menempati peringkat 64 dari 65 negara peserta, atau dengan kata lain menempati peringkat kedua terbawah dari seluruh negara peserta PISA yang disurvey dengan skor rata-rata kemampuan matematika siswa Indonesia yaitu 375, skor tersebut di bawah rata-rata skor internasional yaitu 494. Faktor yang menjadi penyebab dari rendahnya prestasi siswa Indonesia dalam PISA yaitu lemahnya kemampuan pemecahan masalah soal non-routine atau level tinggi. Soal yang diujikan dalam PISA terdiri atas 6 level (level 1 terendah dan level 6 tertinggi) dan soal-soal yang diujikan merupakan soal kontekstual, permasalahannya diambil dari dunia nyata. Siswa di Indonesia hanya terbiasa dengan soal-soal rutin pada level 1 dan level 2. Dapat disimpulkan bahwa kemampuan pemecahan masalah matematika siswa Indonesia rendah.

Berdasarkan hasil observasi awal peneliti di SMP Tunas Baru Jin Seung Kota Batam, kemampuan pemecahan masalah matematis siswa masih rendah. Terlihat bahwa $18 \%$ siswa mampu memahami masalah, $33,3 \%$ siswa mampu membuat rencana, 33,3\% siswa mampu melaksanakan rencana, dan tidak ada siswa yang mamapu tahap memeriksa kembali.

Selain kemampuan pemecahan masalah matematis, aspek afektif juga berperan terhadap keberhasilan seseorang dalam memperoleh pengetahuan dalam belajar. Salah satu aspek afektif tersebut adalah selfefficacy, dimana kemampuan pemecahan masalah matematis erat kaitannya dengan keyakinan siswa dalam menyelesaikan soal. Keyakinan siswa dalam memecahkan masalah akan mempengaruhi siswa dalam setiap langkah-langka penyelesaian masalah yang dilakukan. Pernyataan tersebut sesuai dengan pendapat Bandura (2009), self-efficacy merupakan keyakinan seseorang mengenai kemampuan untuk menyusun dan bertindak dalam mengatur situasi yang akan datang. Keyakinan tersebut mempengaruhi bagaimana seseorang untuk berpikir, bertindak, dan memotivasi dirinya dalam bertindak serta memperhitungkan berbagai resiko yang akan terjadi. Self-efficacy merupakan suatu penilaian seseorang terhadap kemampuan dirinya dalam memutuskan tindakan yang dibutuhkan untuk mencapai performa yang diinginkan. Penilaian tersebut bersifat subjektif karena menekankan pada keyakinan individu sebagai hasil persepsinya tentang kemampuan yang dirinya miliki.

Menurut Sunaryo (2017) self-efficacy matematika memiliki kontribusi positif serta peranan yang sangat penting terhadap prestasi belajar matematika yang dapat dicapai oleh siswa. Self-efficacy membantu seseorang dalam menentukan pilihan, usaha mereka untuk maju, kegigihan dan ketekunan yang mereka tunjukkan dalam menghadapi kesulitan, dan derajat kecemasan atau ketenangan yang mereka alami saat 
mereka mempertahankan tugas-tugas yang mencakup kehidupan mereka. Fitriani (2017) menyatakan bahwa self-efficacy merupakan kemampuan seseorang dalam melakukan tugas dan tindakan untuk menggapai apa yang menjadi tujuannya. Self-efficacy yang dimaksud bukanlah yang berkaitan dengan kepribadian, ciri fisik atau karakteristik seseorang, bukan juga tentang kecakapan yang dimiliki, tetapi yang berkaitan dengan bagaimana seseorang mampu meyakini dirinya untuk bisa melakukan sesuatu untuk mencapai tujuannya atau memotivasi diri agar berpikir jika ia bisa.

Menurut Bandura (1997), yang menjadi indikator dalam self-efficacy yaitu: dimensi magnitude, strength dan generality. Magnitude mengacu pada pengurutan tugas-tugas menurut tingkat kesulitannya. Strength mengacu pada kepercayaan yang ada dalam diri seseorang yang dapat diwujudkan untuk meraih performa tertentu. Generality mengacu pada keleluasaan dari self-efficacy yang dimiliki seseorang dapat diterapkan dalam situasi lain. Masing-masing dimensi memberikan implikasi penting bagi performen seseorang.

Guru sebagai salah satu komponen dalam sistem pembelajaran harus mampu mengembangkan selfefficacy matematis siswa. Guru tidak hanya mengembangkan kemampuan pada ranah kognitif dan ranah psikomotor yang ditandai dengan penguasaan materi pelajaran dan ketrampilan, tetapi juga harus mengembangkan kemampuan ranah kepribadian siswa. Pada ranah ini, siswa harus ditumbuhkan rasa percaya dirinya (self-efficacy) sehingga menjadi manusia yang mampu mengenal dirinya sendiri yakni manusia yang berkepribadian yang mantap dan mandiri, manusia utuh yang memiliki kemantapan emosional dan intelektual, yang mengenal dirinya, mengendalikan dirinya dengan konsisten, dan memiliki rasa empati serta memiliki kepekaan terhadap permasalahan yang dihadapi baik dalam dirinya maupun dengan orang lain (Moma, 2014).

Self-efficacy siswa dalam matematika merupakan salah satu yang menjadi perhatian TIMSS untuk diteliti. Hasil evaluasi TIMSS 2011 dari 63 negara dengan mengajukan 9 pernyataan dengan masingmasing empat alternatif jawaban diperoleh $34 \%$ siswa yang confident, $46 \%$ siswa somewhat confident, dan $21 \%$ siswa not confident. Hasil evaluasi untuk Indonesia, self-efficacy siswa kelas VIII terhadap matematika hanya memiliki $3 \%$ siswa yang confident, $52 \%$ siswa somewhat confident, dan $45 \%$ siswa not confident.

Berdasarkan hasil wawancara dengan salah satu guru matamatika di SMP Tunas Baru Jin seung Batam, dalam proses pembelajaran guru jarang memberikan perhatian yang proporsional dalam meningkatkan selfefficacy matematis siswa. Hal ini dikarenakan guru lebih berfokus pada kemampuan kognitif siswa, tanpa memperhatikan kemampuan afektif terutama kemampuan self-efficacy matematis siswa. Dalam proses pembelajaran siswa sering tidak yakin dengan kemampuan yang dimilikinya dan cenderung menghindar dari soal tersebut. Contohnya: ketika guru memberikan soal yang bentuknya berbeda dengan contoh soal untuk diselesaikan, mereka terkadang bingung dan kurang yakin dengan diri mereka untuk menyelesaikannya dan kebanyakan berakhir dengan menyerah untuk tidak mengerjakan. Artinya, ketika dihadapkan pada soal yang susah kebanyakan siswa langsung menyerah tanpa mencoba terlebih dahulu menyelesaikannya atau terkadang mereka mencoba melewatkan soal yang dianggap susah dan melanjutkan menyelesaikan soal yang dianggap mudah terlebih dahulu. Rendahnya self-efficacy siswa juga ditandai oleh perilaku siswa yang malu mengungkapkan pendapat/jawaban dan juga tidak aktif dalam mengikuti pelajaran matematika.

Salah satu usaha guru untuk memperbaiki proses pembelajaran adalah dengan memilih model pembelajaran yang tepat dan inovatif dalam pembelajaran matematika. Namun kenyataan di lapangan berdasarkan hasil wawancara dengan guru matematika di SMP Tunas Baru Jin Seung Batam, guru masih menggunakan model pembelajaran konvensional saat mengajar yang membuat pembelajaran kurang bermakna. Artinya, dalam proses pembelajaran siswa tidak mengalami sendiri bagaimana proses matematika ditemukan dan siswa terbiasa menghafal konsepkonsep atau fakta-fakta matematika. Guru masih menganut paradigma transfer of knowledge dalam pembelajaran, dimana guru sekedar mentransfer ilmunya dan tidak memberi kesempatan siswa untuk mengeksplorasi kemampuan matematika yang mereka miliki sehingga siswa terkadang tidak diberikan kesempatan untuk mengembangkan kemampuan yang mereka miliki. Proses pembelajaran yang demikian membuat siswa kurang aktif selama proses pembelajaran, hal ini dikarenakan siswa hanya menerima ilmu yang diberikan oleh guru tanpa mengalami proses.

Pembelajaran yang baik adalah pembelajaran yang mengembangkan cara siswa belajar aktif dalam prosesnya. Pernyataan tersebut sesuai dengan pendapat Chrissanti dan Widjajanti (2015) yang menyatakan bahwa siswa harus mampu berinisiatif dan melibatkan dirinya secara aktif dalam mempelajari matematika. Dengan demikian akan timbul suatu interaksi yang baik antara guru dan siswa dalam proses pembelajaran, sehingga siswa bukan lagi menjadi objek pembelajaran tetapi pusat dari kegiatan pembelajaran.

Salah satu model pembelajaran yang dapat digunakan oleh guru untuk melibatkan peserta didik secara aktif dalam meningkatkan kemampuan pemecahan masalah matematis siswa adalah model Problem-Based Learning (PBL). Hal ini sesuai dengan pernyataan Bern dan Erickson (2001) menyatakan bahwa PBL merupakan strategi pembelajaran yang melibatkan siswa dalam memecahkan masalah dengan mengintegrasikan berbagai konsep dan keterampilan dari berbagai disiplin ilmu. Strategi tersebut terdiri dari mengumpulkan dan menyatukan informasi, dan mempersentasikan penemuan. Hasil penelitian Napitupulu (2011) menunjukkan bahwa kemampuan pemecahan masalah matematis siswa di kelas PBM lebih baik daripada kemampuan yang sama di kelas biasa, dimana kemampuan pemecahan masalah 
matematis siswa berkategori KAM tinggi di kelas PBM lebih baik dari pada kemampuan siswa berkategori sama di kelas biasa. Namun untuk kategori KAM sedang dan kurang, tidak ditemukan adanya perbedaan kemampuan tersebut.

Menurut Arends (2012), PBL atau yang sering disebut Pembelajaran Berbasis Masalah (PBM) merupakan suatu pembelajaran di mana peserta didik mengerjakan permasalahan yang otentik dengan maksud untuk menyusun pengetahuan mereka sendiri, mengembangkan inkuiri dan keterampilan berpikir tingkat lebih tinggi, mengembangkan kemandirian, dan percaya diri. PBM tidak dirancang untuk membantu guru menyampaikan informasi dalam jumlah besar kepada siswa seperti pada pembelajaran langsung dan ceramah, tetapi dirancang untuk membantu siswa mengembangkan keterampilan berpikir, keterampilan menyelesaikan masalah dan keterampilan intelektualnya, melalui pengorganisasian pelajaran di seputar situasi-situasi kehidupan nyata.

\section{KAJIAN TEORITIS}

\section{Kemampuan Pemecahan Masalah Matematis}

Seseorang dikatakan menghadapi masalah apabila ingin mencapai suatu tujuan tetapi tidak segera dapat mencapai atau tidak tersedia langkah-langkah yang jelas untuk mencapai tujuan itu. Dalam pembelajaran matematika, masalah adalah suatu persoalan atau pertanyaan yang bersifat menantang yang tidak dapat diselesaikan dengan prosedur rutin yang sudah biasa dilakukan atau sudah diketahui. Hal tersebut sesuai dengan pendapat Muhardhikawati, Mardiyana, dan Setiawan (2017) yang menyatakan suatu soal disebut masalah bagi seorang siswa, jika: (1) Pertanyaan yang dihadapkan dapat dimengerti oleh siswa, namun pertanyaan itu harus merupakan tantangan baginya untuk menjawab; (2) Pertanyaan tersebut tidak dapat dijawab dengan prosedur rutin yang telah diketahui oleh siswa.

Menurut Polya (1973), pemecahan masalah adalah usaha mencari jalan keluar dari suatu kesulitan, mencapai tujuan yang tidak dengan mudah dapat dicapai. Polya mengelompokkan masalah dalam matematika menjadi dua kelompok yaitu :

1. Masalah untuk menemukan, dapat teoritis atau praktis, abstrak atau konkret, termasuk teka-teki. Bagian utama dari suatu masalah adalah apa yang dicari, bagaimana data yang diketahui, dan bagaimana syaratnya. Ketiga bagian utama tersebut merupakan landasan untuk dapat menyelesaikan masalah jenis ini.

2. Masalah untuk membuktikan adalah menunjukkan bahwa suatu pernyataan itu benar, salah, atau tidak kedua-duanya. Bagian utama dari masalah ini adalah hipotesis dan konklusi dari suatu teorema yang harus dibuktikan kebenarannya. Kedua bagian utama tersebut sebagai landasan utama untuk dapat menyelesaikan masalah jenis ini.

Polya (1973) berpendapat bahwa ada empat tahap dalam menyelesaikan masalah, yaitu:

1. Memahami Masalah
2. Merencanakan Pemecahan Masalah

3. Melaksanakan Rencana

4. Melihat Kembali

\section{Self-Efficacy Siswa}

Bandura (1998) berpendapat bahwa perceived selfefficacy refers to beliefs in one's capabilities to organize and execue the course of action required to produce given attainments. Artinya self-efficacy mengacu pada kemampuan seseorang untuk mengatur dan menyelesaikan tindakan yang diperlukan utuk mencapai tujuan tertentu. Keyakinan individu dapat memberikan efek terhadap tindakan dan mempengaruhi pilihan mereka, aspirasi mereka, ketekunan, dan tingkat setres atau depresi.

Bandura (1998) mengungkapkan bahwa selfefficacy terdiri dari tiga dimensi, yaitu:

1. Level

2. Strenght

3. Magnitude

\section{Pembelajaran Berbasis Masalah}

Menurut Arends (2012) pembelajaran berdasarkan masalah (PBM) merupakan suatu pembelajaran di mana peserta didik mengerjakan permasalahan yang otentik dengan maksud untuk menyusun pengetahuan mereka sendiri, mengembangkan inkuiri dan keterampilan berpikir tingkat lebih tinggi, mengembangkan kemandirian, dan percaya diri. Melalui PBM siswa diharapkan akan berfokus pada kegiatan memecahkan masalah. Dalam kegiatan memecahkan masalah tersebut siswa memiliki kesempatan yang luas untuk dapat bertukar ide atau pendapat dengan siswa lainnya sehingga memperoleh pemahaman baru tentang matematika yang disisipkan dalam masalah tersebut.

Arends (2012) berpendapat bahwa karakteristik pembelajaran masalah menurut berbagai pengembang pengajaran berbasis masalah yaitu:

1. Pengajuan masalah yang menantang;

2. Fokus Interdisipliner;

3. Investigasi autentik;

4. Menghasilkan produk dan memamerkannya; dan

5. Kolaborasi.

Adapun langka-langkah model PBM menurut Arends (2012), yaitu :

1. Mengorientasi peserta didik kepada masalah;

2. Mengorganisasi peserta didik untuk belajar;

3. Membimbing penyelidikan individual maupun kelompok;

4. Mengembangkan dan menyajikan hasil karya;

Menganalisis dan mengevaluasi proses pemecahan masalah.

\section{METODE PENELITIAN}

Jenis penelitian yang digunakan dalam penelitian ini adalah penelitian deskriptif kualitatif. Subjek dalam penelitian ini adalah melibatkan siswa kelas VII SMP Tunas Baru Jin Seung Kota Batam yaitu siswa kelas VII-A yang berjumlah 38 orang. 
Vol. 13, No.1, Juni 2020

Kriteria pengambilan subjek adalah dengan menggunakan dua kriteria yaitu berdasarkan tingkat kemampuan pemecahan masalah matematis dan berdasarkan self-efficacy siswa. Melalui kacamata lembar jawaban, siswa dikelompokkan berdasarkan tiga kategori jawaban yaitu: (1) siswa dengan lembar jawaban berkemampuan tinggi; (2) siswa dengan lembar jawaban berkemampuan sedang; dan (3) siswa dengan lembar jawaban berkemampuan rendah. Melalui kacamata self-efficacy, siswa yang telah dikelompokkan berdasarkan tingkat kemampuan pemecahan masalah matematis akan dianalisis berdasarkan dimensi self-efficacy yaitu tingkat (level), keluasan (generality), dan kekuatan (strength).

Objek dalam penelitian ini adalah kemampuan pemecahan masalah matematis dan self-efficacy siswa yang diberi perlakukan model PBL. Objek dalam penelitian ini dapat dilihat melalui hasil tes kemampuan pemecahan masalah matematis dari lembar jawaban siswa, dan hasil wawancara berupa transkip, kemudian self-efficacy dapat dilihat dari skala self-efficacy siswa.

\section{HASIL PENELITIAN}

\section{Deskripsi Kemampuan Pemecahan Masalah Matematis Siswa Setelah Pembelajaran PBL}

Deskripsi kemampuan pemecahan masalah matematis siswa diperoleh berdasarkan skor setiap masing-masing siswa berdasarkan hasil tes kemampuan pemecahan masalah matematis dan wawancara. Secara kuantitaif, tingkat kemampuan pemecahan masalah matematis siswa dapat dilihat pada Tabel 1.

Tabel 1 Tingkat Kemampuan Pemecahan Masalah Matematis Siswa

\begin{tabular}{lcccc}
\hline $\begin{array}{l}\text { Tingkat SPMM } \\
\text { Sumlah } \\
\text { Siswa }\end{array}$ & $\begin{array}{c}\text { Persent } \\
\text { ase }\end{array}$ & $\begin{array}{c}\text { Kategori } \\
\text { Penilaian }\end{array}$ \\
\hline $\begin{array}{l}65 \leq S 1 \\
<80\end{array}$ & $<65$ & 10 & $26 \%$ & Rendah \\
\hline $80 \leq S 1$ & $<101$ & 8 & $21 \%$ & Tinggi \\
\hline
\end{tabular}

Ket: SPMM = Skor Pemecahan Masalah Matematis

Berdasarkan Tabel 1 di atas terlihat bahwa persentase kemampuan pemecahan masalah matematis siswa berkemampuan tinggi lebih rendah dibandingkan kemampuan sedang dan kemampuan rendah. Persentase siswa berkemampuan rendah dua kali lipat dari persentase siswa berkemampuan sedang.

Lembar jawaban siswa dianalisis berdasarkan tahapan-tahapan Polya. Secara kuantitatif, persentase tingkat kemampuan pemecahan masalah matematis siswa berdasarkan tahapan Polya dapat dilihat pada Tabel 2.

Tabel 2 Kemampuan Pemecahan Masalah Matematis Siswa Berdasarkan Tahapan Polya

\begin{tabular}{lcc}
\hline $\begin{array}{l}\text { Tahapan Pemecahan } \\
\text { Masalah Matematis }\end{array}$ & $\begin{array}{c}\text { Jumlah } \\
\text { Siswa }\end{array}$ & Persentase \\
\hline Memahami Masalah & 38 orang & $100 \%$ \\
\hline Membuat Rencana & 21 orang & $55 \%$ \\
\hline Melaksanakan Rencana & 16 orang & $42 \%$ \\
\hline Memeriksa Kembali & 5 orang & $13 \%$ \\
\hline
\end{tabular}

Berdasarkan Tabel 2 di atas terlihat persentase siswa kelas VII-A dalam menyelesaikan soal pemecahan masalah matematis berdasarkan tahapan Polya. Urutan persetase tahap pemecahan masalah matematis siswa dari tertinggi ke rendah yaitu tahap memahami masalah, diikuti tahap membuat rencana, tahap melaksanakan rencana dan terakhir tahap memeriksa kembali.

\section{Deskripsi Kemampuan Pemecahan Masalah}

Matematis Siswa Berkemampuan Tinggi

Lembar jawaban siswa berkemampuan tinggi dianalisis berdasarkan tahapan-tahapan Polya. Secara kuantitatif, klasifikasi kemampuan pemecahan masalah matematis siswa berkemampuan tinggi berdasarkan tahapan Polya dapat dilihat pada Tabel 3.

Tabel 3 Klasifikasi Hasil Tes Kemampuan Pemecahan Masalah Siswa Berkemampuan Tinggi

\begin{tabular}{|c|c|c|c|}
\hline \multirow{2}{*}{$\begin{array}{l}\text { Tahap-tahap } \\
\text { Pemecahan } \\
\text { Masalah } \\
\text { Matematis }\end{array}$} & \multicolumn{3}{|c|}{ Banyak Siswa (Persentase) } \\
\hline & $\begin{array}{c}\text { Jawaban } \\
\text { Benar }\end{array}$ & $\begin{array}{l}\text { Jawaban } \\
\text { Salah }\end{array}$ & $\begin{array}{c}\text { Tidak } \\
\text { Menjawab }\end{array}$ \\
\hline $\begin{array}{l}\text { Memahami } \\
\text { Masalah }\end{array}$ & $\begin{array}{l}8 \text { Orang } \\
(100 \%)\end{array}$ & - & - \\
\hline $\begin{array}{c}\text { Membuat } \\
\text { Rencana }\end{array}$ & $\begin{array}{l}8 \text { Orang } \\
(100 \%)\end{array}$ & - & - \\
\hline $\begin{array}{c}\text { Melaksanakan } \\
\text { Rencana }\end{array}$ & $\begin{array}{l}7 \text { Orang } \\
(87,5 \%) \\
\end{array}$ & $\begin{array}{l}\text { 1 Orang } \\
(13 \%)\end{array}$ & - \\
\hline $\begin{array}{l}\text { Memeriksa } \\
\text { Kembali }\end{array}$ & $\begin{array}{l}5 \text { Orang } \\
(62,5 \%) \\
\end{array}$ & $\begin{array}{l}2 \text { Orang } \\
(25 \%)\end{array}$ & $\begin{array}{l}\text { 1 Orang } \\
(12,5 \%)\end{array}$ \\
\hline $\begin{array}{l}\text { Berdasarkan } \\
\text { kemampuan } \\
\text { berdasarkan taha } \\
\text { tinggi, dimana } \\
\text { terdapat jawaban } \\
\text { terdapat jawaban }\end{array}$ & $\begin{array}{l}\text { Tabel } 3 \text { di } \\
\text { emecahan } \\
\text { p Polya pad } \\
\text { bada tahap } \\
\text { salah dan ta } \\
\text { salah serta tic }\end{array}$ & $\begin{array}{l}\text { atas terlihat } \\
\text { masalah } \\
\text { la siswa berk } \\
\text { melaksanakka } \\
\text { ahap memerik } \\
\text { dak menjawab. }\end{array}$ & $\begin{array}{r}\text { klasifikasi } \\
\text { matematis } \\
\text { kemampuan } \\
\text { an rencana } \\
\text { ksa kembali }\end{array}$ \\
\hline
\end{tabular}

\section{Deskripsi Kemampuan Pemecahan Masalah}

Matematis Siswa Berkemampuan Sedang

Lembar jawaban siswa berkemampuan sedang dianalisis berdasarkan tahapan-tahapan Polya. Secara kuantitatif, klasifikasi kemampuan pemecahan masalah matematis siswa berkemampuan sedang berdasarkan tahapan Polya dapat dilihat pada Tabel 4.

Tabel 4 Klasifikasi Hasil Tes Kemampuan Pemecahan Masalah Siswa Berkemampuan Sedang

\begin{tabular}{lccc}
\hline $\begin{array}{l}\text { Tahap-tahap } \\
\text { Pemecahan }\end{array} \begin{array}{l}\text { Masalah } \\
\text { Matematis }\end{array}$ & $\begin{array}{c}\text { Jawaban } \\
\text { Benar }\end{array}$ & $\begin{array}{c}\text { Jawaban } \\
\text { Salah }\end{array}$ & $\begin{array}{c}\text { Tidak } \\
\text { Menjawab }\end{array}$ \\
\cline { 2 - 4 } $\begin{array}{l}\text { Memahami } \\
\text { Masalah }\end{array}$ & $\begin{array}{c}\text { 20 Orang } \\
(100 \%)\end{array}$ & - & - \\
\hline $\begin{array}{l}\text { Membuat } \\
\text { Rencana }\end{array}$ & $\begin{array}{c}13 \text { Orang } \\
(65 \%)\end{array}$ & $\begin{array}{c}7 \text { Orang } \\
(35 \%)\end{array}$ & - \\
\hline $\begin{array}{l}\text { Melaksanakan } \\
\text { Rencana }\end{array}$ & $\begin{array}{c}\text { Orang } \\
(45 \%)\end{array}$ & $\begin{array}{c}11 \text { Orang } \\
(55 \%)\end{array}$ & - \\
\hline $\begin{array}{l}\text { Memeriksa } \\
\text { Kembali }\end{array}$ & - & $\begin{array}{c}14 \\
\text { Orang } \\
(70 \%)\end{array}$ & $\begin{array}{c}\text { 6 Orang } \\
(30 \%)\end{array}$ \\
\hline
\end{tabular}

Berdasarkan Tabel 4 di atas terlihat klasifikasi kemampuan pemecahan masalah matematis berdasarkan tahap Polya pada siswa berkemampuan 
Vol. 13, No.1, Juni 2020

sedang, dimana seluruh siswa kemapuan sedang hanya mampu menjawab dengan benar tahap memahami masalah. Terdapat kesalahan jawaban yang dilakukan bebesarapa siswa pada tahap membuat rencan, dan tahap melaksanakn rencana. Pada tahap memeriksa kembali, seluruh siswa berkemampuan sedang salah menjawab bahkan ada yang tidak menjawab.

4. Deskripsi Kemampuan Pemecahan Masalah Matematis Siswa Berkemampuan Rendah

Lembar jawaban siswa berkemampuan rendah dianalisis berdasarkan tahapan-tahapan Polya. Secara kuantitatif, klasifikasi kemampuan pemecahan masalah matematis siswa berkemampuan tinggi berdasarkan tahapan Polya dapat dilihat pada Tabel 5

Tabel 5 Klasifikasi Hasil Tes Kemampuan Pemecahan Masalah Siswa Berkemampuan Rendah

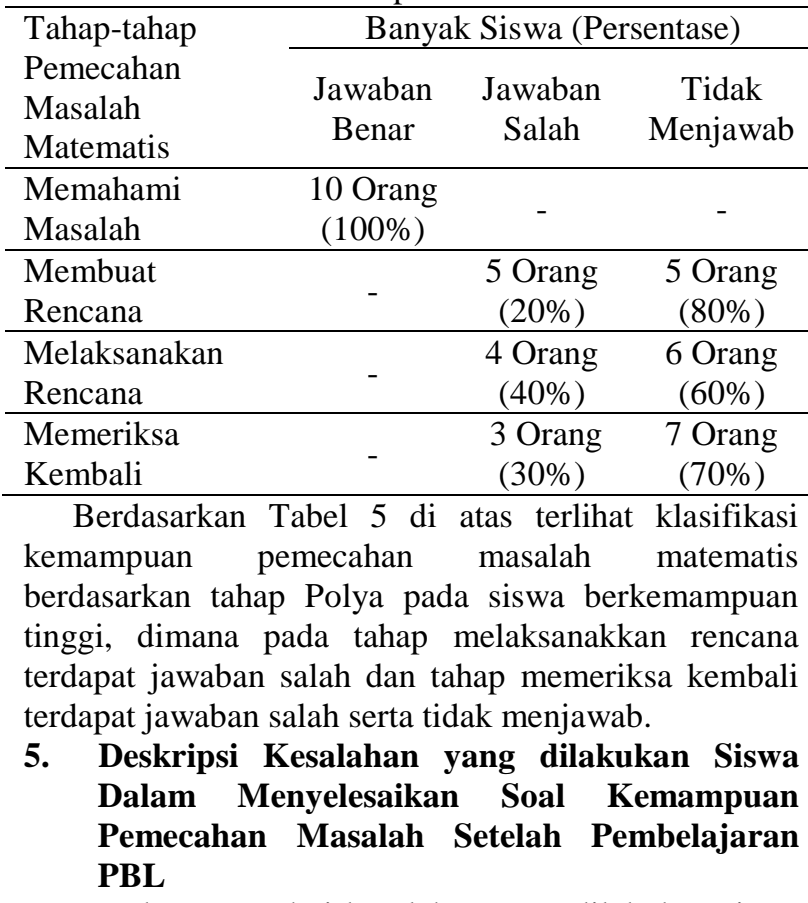

Untuk mengetahui kesalahan yang dilakukan siswa dalam menyelesaian soal pemecahan masalah matematis dilakukan analisis lebih mendalam mengenai hasil tes. Lembar jawaban siswa berkemampuan tinggi dianalisis berdasarkan tahaptahap Polya. Secara kuantitatif, klasifikasi kemampuan pemecahan masalah matematis siswa berkemampuan tinggi berdasarkan tahap Polya dapat dilihat pada Tabel 6.

Tabel 6 Persentase Kesalahan yang dilakukan Siswa dalam Menyelesaika Soal Pemecahan Masalah Matematis

\begin{tabular}{lccc}
\hline Tahap-Tahap & \multicolumn{3}{c}{ Banyak Siswa (Persentase) } \\
\cline { 2 - 4 } $\begin{array}{l}\text { Pemecahan } \\
\text { Masalah }\end{array}$ Matematis & $\begin{array}{c}\text { Jawaban } \\
\text { Benar }\end{array}$ & $\begin{array}{c}\text { Jawaban } \\
\text { Salah }\end{array}$ & $\begin{array}{c}\text { Tidak } \\
\text { Menjawab }\end{array}$ \\
\hline $\begin{array}{l}\text { Memahami } \\
\text { Masalah }\end{array}$ & $\begin{array}{c}38 \text { Orang } \\
(100 \%)\end{array}$ & - & - \\
\hline $\begin{array}{l}\text { Membuat } \\
\text { Rencana }\end{array}$ & $\begin{array}{c}\text { 21 Orang } \\
(55 \%)\end{array}$ & $\begin{array}{c}12 \text { Orang } \\
(32 \%)\end{array}$ & $\begin{array}{c}5 \text { Orang } \\
(13 \%)\end{array}$ \\
\hline Melaksanakan & 16 Orang & 16 Orang & 6 Orang \\
Rencana & $(42 \%)$ & $(42 \%)$ & $(16 \%)$ \\
\hline Memeriksa & 5 Orang & 19 Orang & 14 Orang \\
\hline
\end{tabular}

Kembali

$(13 \%)$

$(50 \%)$

$(37 \%)$

Berdasarkan Tabel 6 di atas, terlihat kesalahan yang dilakukan siswa dalam menyelesaikan soal kemampuan pemecahan masalah matematis ada dua yaitu kesalahan jawaban dan tidak menjawab. Kesalahan yang paling banyak dilakuan yaitu pada tahap memeriksa kembali, diikuti tahap melaksanakan rencana dan selanjutnya tahap membuat rencana.

\section{Deskripsi Self-Efficacy Siswa Setelah Pembelajaran PBL}

Deskripsi self-efficacy siswa diperoleh berdasarkan skor setiap masing-masing siswa berdasarkan pengisian pada skala self-efficacy. Seluruh lembar jawaban siswa dari hasil self-efficacy dikumpulkan untuk diperiksa dan diberi skor. Skala self-efficacy terdiri dari 32 butir item dengan tiga dimensi self-efficacy yaitu level yang berhubungan dengan taraf kesulitan tugas, strenght yang berkaitan dengan kekuatan penilaian kecakapan individu dan generality merupakan suatu konsep bahwa efikasi diri seseorang tidak terbatas pada situasi yang spesifik saja.

Secara kuantitaif, tingkat self-efficacy siswa dapat dilihat pada Tabel 7

Tabel 7 Hasil Penggolongan Tingkat Self-Efficacy Siswa

\begin{tabular}{lccc}
\hline Rentang Skor & $\begin{array}{c}\text { Jumlah } \\
\text { Siswa }\end{array}$ & $\begin{array}{c}\text { Persentas } \\
\mathrm{e}\end{array}$ & Kategori \\
\hline $\bar{X} \geq 17,2$ & 0 & $0 \%$ & $\begin{array}{c}\text { Sangat } \\
\text { Rendah }\end{array}$ \\
\hline $\begin{array}{l}17,2 \leq \bar{X} \\
<34,4\end{array}$ & 12 & $31,58 \%$ & Rendah \\
\hline $\begin{array}{l}34,4 \leq \bar{X} \\
<51,6\end{array}$ & 18 & $47,37 \%$ & Sedang \\
\hline $\begin{array}{l}51,6 \leq \bar{X} \\
<68,8\end{array}$ & 6 & $15,79 \%$ & Tinggi \\
\hline $\bar{X}<68,8$ & 2 & $5,26 \%$ & $\begin{array}{l}\text { Sangat } \\
\text { Tinggi }\end{array}$ \\
\hline
\end{tabular}

Berdasarkan Tabel 7 di atas terlihat klasifikasi selfefficacy siswa, urutan self-efficacy siswa dari yang paling banyak yaitu pada kategori sedang, diikuti kategori rendah, kategori tinggi dan terakkhir kategori sangat tinggi.

Terdapat tiga dimensi self-efficacy menurut Bandura, yaitu magnitude, strenght dan generality. Secara kuantitaif, pengelompokan self-efficacy siswa berdasarkan dimensi Bandura dapat dilihat pada Tabel 8 .

Tabel 8 Pengelompokan Siswa Berdasaran Dimensi Bandura

\begin{tabular}{|c|c|c|c|c|}
\hline No & Dimensi & Tingkat & $\begin{array}{c}\text { Jumlah } \\
\text { Siswa }\end{array}$ & Persentase \\
\hline \multirow{4}{*}{1} & \multirow{4}{*}{ Magnitude } & $\begin{array}{c}\text { Sangat } \\
\text { Tinggi }\end{array}$ & 1 & $7,69 \%$ \\
\hline & & Tinggi & 2 & $15,38 \%$ \\
\hline & & Sedang & 6 & $46,15 \%$ \\
\hline & & Rendah & 4 & $30,77 \%$ \\
\hline \multirow{3}{*}{2} & \multirow{3}{*}{ Strenght } & $\begin{array}{l}\text { Sangat } \\
\text { Tinggi }\end{array}$ & 0 & $0 \%$ \\
\hline & & Tinggi & 2 & $11,76 \%$ \\
\hline & & Sedang & 8 & $47,06 \%$ \\
\hline
\end{tabular}




\begin{tabular}{|c|c|c|c|c|}
\hline \multirow{5}{*}{3} & & Rendah & 7 & $41,18 \%$ \\
\hline & \multirow{4}{*}{ Generality } & $\begin{array}{l}\text { Sangat } \\
\text { Tinggi }\end{array}$ & 1 & $12,50 \%$ \\
\hline & & Tinggi & 2 & $25 \%$ \\
\hline & & Sedang & 4 & $50 \%$ \\
\hline & & Rendah & 1 & $12,50 \%$ \\
\hline
\end{tabular}

Berdasarkan tabel 8 terlihat self-efficacy siswa lebih dominan berada pada dimensi strenght berjumlah 17 orang, diikuti magnitude berjumlah 13 orang dan terakhir generality berjumlah 8 orang.

\section{PEMBAHASAN}

Pada bagian ini dilakuan penarikan kesimpulan terhadap data temuan penelitian dari kemampuan pemecahan masalah matematis, dan self-efficacy siswa. Berdasarkan data yang diperoleh dari hasil analisis akan diketahui apakah rumusan masalah dan pertanyaan penelitian yang diajukan telah terjawab atau belum.

\section{Analisis Tingkat Kemampuan Pemecahan Masalah} Matematis Pada Pembelajaran PBL

Pemecahan masalah matematis sering dilihat sebagai salah satu dari sejumlah keterampilan yang diajarkan dalam kurikulum sekolah. Schoenfeld (2016) menempatkan pemecahan masalah matematis dalam hierarki keterampilan yang akan diperoleh oleh siswa mengarah ke konsekuensi tertentu untuk peran pemecahan masalah matematis dalam kurikulum.

Kemampuan pemecahan masalah melalui pembelajaran PBL dapat dideskripsikan dan dibahas sesuai dengan data penelitian untuk tiap tingkat kemampuan dan tingkat tahap pemecahan masalah matematis. Berdasarkan hasil tertulis yang telah dilakukan dapat disimpulkan bahwa persentase kemampuan pemecahan masalah matematis siswa berkemampuan tinggi lebih rendah dibandingkan kemampuan sedang dan kemampuan rendah. Persentase siswa berkemampuan rendah dua kali lipat dari persentase siswa berkemampuan sedang.

Siswa dikatakan mampu memecahkan masalah jika dalam menyelesaikan soal pemecahan masalah melakukan 4 tahapan, yaitu: (1) Memahami masalah (understand the problem); (2) Menyusun rencana (devise a plan); (3) Melaksanakan rencana (carry out a plan); dan (4) Memeriksa kembali (look back) (Polya, 1973). Dalam penelitian ini telah digunakan 4 butir soal untuk mengungkapkan kinerja siswa terhadap pemecahan masalah matematis siswa dimana masingmasing butir soal mencakup tahapan pemecahan masalah matematis.

Berdasarkan hasil penelitian diperoleh gambaran kemampuan pemecahan masalah matematis siswa berdasarkan tahapan Polya: Siswa dengan kemampuan tinggi mampu memahami masalah (understand the problem). Hal ini ditandai dengan mampu menuliskan apa yang diketahui dan ditanyakan pada soal, mampu menjelaskan masalah tersebut dengan menggunakan kalimat sendiri pada saat wawancara, mampu menyederhanakan masalah dan mampu mencari sub tujuan serta mampu mengurutkan informasi yang ada pada soal. Pada tahap menyusun rencana (devise a

plan) siswa mampu memahami keterkaitan antara diketahui dan ditanyakan, dapat membuat perencanaan atau strategi dalam menyelesaikan masalah, serta dapat menentukan operasi matematika yang digunakan dalam menyelesaikan masalah. Pada tahap melaksanakan rencana (carry out a plan) siswa mampu melaksanakan rencana penyelesaian yang telah dibuat dengan perhitungan yang benar. Pada tahap memeriksa kembali (look back), siswa mampu menafsirkan hasil akhir yang diperoleh dari jawaban sebelumnya kedalam konteks masalah serta memberikan argumennya.

Hal ini sesuai dengan hasil penelitian Saparwadi dan Cahyowatin (2018) yang menyatakan siswa berkemampuan tinggi mampu memahami masalah dengan memahami kosa kata soal, mengidentifikasi semua fakta berupa data informasi yang ada dalam soal tes, menghubungkan antar semua informasi dari hasil identifikasi, dan diakhiri dengan mengidentifikasi pertanyaan dari soal pada instrument tes pemecahan masalah sebagai tujuan yang ingin dicapai. Mampu menyususn rencana pemecahan dengan pemilihan operasi berdasarkan hasil identifikasi semua data informasi dalam masalah. Mampu lekasanakan rencana dan mampu memeriksa kembali hasil yang diperoleh yaitu dengan cara mensubtitusikan hasil yang telah diperoleh ke persamaan awal. Kesesuaian hasil subtitusi tersebut ke persamaan awal menunnjukkan bahwa hasil yang diperoleh siswa adalah benar dan sudah tercapainya tujuan berdasarkan solusi dari masalah yang dihadapi siswa.

Siswa dengan kemampuan sedang pada tahap memahami masalah (understand the problem) mampu menuliskan apa yang diketahui dan ditanyakan pada soal, mampu menjelaskan masalah tersebut dengan menggunakan kalimat sendiri pada saat wawancara, mampu mencari subtujuan, serta mampu mengurutkan informasi yang ada pada soal. Pada tahap menyusun rencana (devise a plan) siswa mampu memahami keterkaitan antara diketahui dan ditanyakan, serta dapat membuat perencanaan atau strategi dalam menyelesaikan masalah. Pada tahap melaksanakan rencana (carry out a plan) siswa mampu melaksanakan rencana penyelesaian yang telah dibuat dengan perhitungan yang benar. Pada tahap memeriksa kembali (look back) siswa belum mampu menafsirkan hasil akhir yang diperoleh kedalam konteks masalah dan memberikan argumen. siswa hanya mampu membuat kesimpulan dari penyelesaian yang dia buat.

Hal ini sesuai dengan hasil penelitian Rianti (2018) yang menyatakan bahwa siswa berkemampuan sedang mampu memahami masalah dengan menuliskan apa yang diketahui dan ditanyakan pada soal, kurang mampu membuat rencana penyelesain yaitu menuliskan rumus yang dapat digunakan untuk menyelesaikan persoalan walaupun belum lengkap. Siswa kurang mampu melaksanakan rencana dan sangat kurang dalam memeriksa kembali hasil.

Siswa dengan kemampuan rendah pada tahap memahami masalah (understand the problem) mampu menuliskan apa yang diketahui dan ditanyakan pada soal, namun tidak mampu menjelaskan kembali masalah dengan kalimat sendiri pada saat wawancara. 
Pada tahap menyusun rencana (devise a plan) siwa dapat memahami keterkaitan antara diketahui dan ditanyakan namun tidak dapat membuat perencanaan atau strategi dalam menyelesaikan masalah, serta tidak mampu mengurutkan informasi yang ada pada soal. Pada tahap melaksanakan rencana (carry out a plan) siswa tidak mampu membuat tahap penyelesaian. Pada tahap memeriksa kembali (look back), siswa tidak mampu menafsirkan hasil akhir yang diperoleh kedalam konteks masalah dan memberikan argumen. Siswa hanya mampu menarik kesimpulan tanpa dikaitkan kembali dengan permasalahan.

Berdasarkan penelitian yang dilakukan, persentase kemampuan siswa untuk tahap memahami masalah sebesar $100 \%$, tahap merencanakan masalah sebesar $55 \%$, tahap melaksanakan rencana sebesar $42 \%$, dan tahap memeriksa kembali sebesar 13\%. Hasil penelitian tersebut relevan dengan penelitian Lubis, Panjaitan, Surya dan Syahputra (2017) menunjukkan persentase kemampuan siswa untuk memahami masalah mencapai $87,10 \%$ dan dalam kategori sangat baik, persentase kemampuan pemecahan masalah siswa untuk merencanakan $40,32 \%$ pada kategori tidak menguntungkan, persentase kemampuan siswa untuk menyelesaikan masalah sesuai dengan rencana $21.19 \%$ diklasifikasikan dalam sangat kurang, persentase kemampuan siswa untuk memeriksa kembali hasil yang diperoleh $48.39 \%$ dalam kategori yang tidak menguntungkan.

Penelitian Paranginangin dan Surya (2017) juga menunjukkan bahwa persentase kemampuan pemecahan masalah siswa pada tahap pertama pemecahan masalah understanding the problem adalah $75,08 \%$, tahap kedua devising a plan to solve the problem adalah $66,12 \%$, tahap ketiga implementing the plan adalah $29,03 \%$, dan tahap keempat reflection on the problem adalah $24,19 \%$.

Berdasarkan hasil penelitian dan pendapat di atas, dapat disimpulkan bahwa siswa berkemampuan tinggi mampu melaksanakan tahapan pemecahan masalah dengan baik dan tepat, sedangkan siswa yang berkemampuan sedang mampu memahami masalah, membuat rencana dan melaksanakan rencana dengan baik. Siswa yang berkemampuan rendah mampu memahami masalah namun kurang mampu dalam membuat rencana, melaksanakan rencana, dan memeriksa kembali.

\section{Analisis Kesalahan yang dilakukan Siswa dalam Menyelesaikan Soal Pemecahan Masalah Matematis}

Berdasarkan hasil temuan penelitian, wawancara yang dilakukan terhadap subjek, dan triangulasi data maka ditemukan beberapa kesalahan siswa dalam menyelesaikan soal-soal berbasis masalah pada materi Bilangan sesuai dengan langkah-langkah pemecahan masalah. Mayoritas kesalahan yang dilakukan siswa dalam menyelesaikan soal pemecahan masalah matematis berada pada tahap memeriksa kembali yaitu sebanyak 19 orang salah jawab dan 14 orang tidak menjawab. Tahap ini jelas menunjukkan ketidaklancaran siswa dalam menafsir hasil yang diperoleh dan memberikan argumennya.
Belajar merupakan kegiatan yang kompleks hal ini sesuai dengan teori Gagne (Dimyati, 2002). Artinya, setelah belajar orang memiliki keterampilan, pengetahuan, sikap, dan nilai. Dengan demikian belajar adalah seperangkat proses kognitif yang mengubah sifat stimulus lingkungan, melewati pengolahan informasi, menjadi kapabilitas baru. Menurut Gagne, objek belajar matematika terdiri dari objek langsung dan tak langsung. Objek langsung belajar matematika adalah fakta, keterampilan, konsep, dan prinsip. Objek tidak langsung adalah transfer belajar, kemampuan menyelidiki, kemampuan memecahkan masalah, disiplin pribadi, dan apresiasi pada struktur matematika.

Pemecahan masalah matematis melibatan lima tahap menurut Gagne (Purwoko, 2017) yaitu: Menyatakan masalah dalam bentuk umum; Menyatakan kembali masalah dalam suatu defenisi operasional; Merumuskan hipotesis alternatif dan prosedur yang mungkin tepat untuk memecahkan masalah; Menguji hipotesis dan melaksanakan prosedur untuk memperoleh solusi; danMenentukan solusi yang tepat. Hal ini sesuai dengan pendapat Polya (1973), siswa dikatakan mampu memecahkan masalah jika dalam menyelesaikan soal pemecahan masalah melakukan 4 tahapan, yaitu: (1) Memahami masalah (understand the problem); (2) Menyusun rencana (devise a plan); (3) Melaksanakan rencana (carry out a plan); dan (4) Memeriksa kembali (look back). Sehingga kesalahan yang dilakukan siswa dalam menyelesaikan soal pemecahan masalah matematis dianalisis berdasarkan tahap pemecahan maslah matematis Polya. Kesalahan dalam konteks belajar mengajar berarti kekeliruan dalam persepsi mata pelajaran/memproduksi kembali memori belajar, seseorang melakukan kesalahan akibat salah dalam mempersepsikan.

Berdasarkan hasil penelitian diperoleh gambaran kesalahan siswa dalam menyelesaikan soal pemecahan masalah matematis: Kesalahan siswa berkemampuan tinggi yaitu pada tahap melaksanakan rencana (carry out a plan), terdapat 1 orang tidak mampu melaksanakan rencana penyelesaian dengan benar yaitu melakukan kesalahan perhitungan. Pada tahap memeriksa kembali (look back), terdapat 2 orang salah dalam menafsirkan hasil akhir yang diperoleh dan tidak memberikan argumennya. Terdapat 1 orang tidak melaksanakan tahap memeriksa kembali. Disimpulkan bahwa kesalahan siswa berkemampuan tinggi dalam menyelesaikan soal pemecahan masalah matematis berada pada tahap melaksanakan rencana dan memeriksa kembali.

Kesalahan siswa berkemampuan sedang yaitu pada tahap membuat rencana, 7 orang salah dalam membuat rencana. Kesalah yang dilakuan siswa yaitu membuat rencana pemecahan masalah yang tidak dapat dilaksanakan, sehingga rencana itu tidak mungkin dapat dilaksanakan. Pada tahap melaksanakan rencana (carry out a plan), terdapat 11 orang tidak mampu melaksanakan rencana penyelesaian dengan benar yaitu melakukan kesalahan perhitungan. Pada tahap memeriksa kembali (look back), terdapat 14 orang 


\section{PARADIKMA JURNAL PENDIDIKAN MATEMATIKA}

Vol. 13, No.1, Juni 2020

salah dalam menafsirkan hasil akhir yang diperoleh dan tidak memberikan argumennya. Terdapat 6 orang tidak melaksanakan tahap memeriksa kembali. Disimpulkan bahwa kesalahan siswa berkemampuan sedang dalam menyelesaikan soal pemecahan masalah matematis berada pada tahap membuat rencana, melaksanakan rencana dan memeriksa kembali.

Kesalahan siswa berkemampuan rendah yaitu pada tahap membuat rencana, 5 orang salah dalam membuat rencana dan 5 orang lagi tidak dapat membuat rencana. Kesalah yang dilakuan siswa yaitu membuat rencana pemecahan masalah yang tidak dapat dilaksanakan, sehingga rencana itu tidak mungkin dapat dilaksanakan. Pada tahap melaksanakan rencana (carry out a plan), terdapat 4 orang tidak mampu melaksanakan rencana penyelesaian dengan benar yaitu melakukan kesalahan perhitungan. Terdapat 6 orang tidak dapat melakuakan tahap melaksanakan rencana. Pada tahap memeriksa kembali (look back), terdapat 3 orang salah dalam menafsirkan hasil akhir yang diperoleh dan tidak memberikan argumennya. Terdapat 7 orang tidak melaksanakan tahap memeriksa kembali. Disimpulkan bahwa kesalahan siswa berkemampuan sedang dalam menyelesaikan soal pemecahan masalah matematis berada pada tahap membuat rencana, melaksanakan rencana dan memeriksa kembali.

Tahap memahami masalah adalah tahap dimana harus mampu memahami bahasa atau istilah yang digunakan dalam masalah tersebut, merumuskan apa yang diketahui, apa yang ditanyakan, apakah informasi yang diperoleh cukup, kondisi/syarat apa saja yang harus terpenuhi, menuliskan masalah dalam bentuk yang lebih operasional sehingga mempermudah untuk dipecahkan. Hung, Chang, and Lin (2012) menyatakan bahwa dalam memahami masalah, harus mengerti arti dari sebuah kalimat, mengidentifikasi yang diketahui, tidak diketahui dan hubungan antar informasi, dan mengetahui konsep yang telah dipelajari sebelumnya yang diperlukan untuk memecahkan masalah. Kesalahan siswa dalam menyelesaikan soal pemecahan masalah matematis pada tahap memahami masalah sebesar $0 \%$, artinya tidak terdapat kesalahan siswa pada tahap memahami masalah. Siswa mampu menuliskan apa yang diketahui dan ditanya dari soal, namun tidak mengerti arti dari sebuah kalimat. Hal ini dibuktikan dengan ketidak mampuan siswa menyebutkan kembali apa yang diketahui dan ditanya tanpa melihat teks sehingga membuat siswa tidak mengerti hubungan antar informasi. Ketidak mampuan menghubungkan informasi mengakibatkan siswa tidak mengetahui konsep matematika yang akan digunakan untuk memecahkan masalah.

Tahap membuat rencana penyelesaian adalah tahap dimana mencari kemungkinan-kemungkinan yang dapat terjadi kemudian menyusun prosedur penyelesaiannya. Ersoy dan Guner (2015) berpendapat penggunaan strategi masalah yang sesuai sangat sangat penting dalam keberhasilan pemecahan masalah. Kesalahan siswa dalam menyelesaikan soal pemecahan masalah matematis pada tahap memahami masalah sebesar 57,9\%. Pada tahap membuat rencana penyelesaian, siswa tidak dapat menentukan apa yang harus dilakukan untuk menyelesaikan masalah sehingga melakukan kesalahan operasi matematika dalam menyusun langkah-langkah penyelesaian. Hal ini dikarenakan siswa tidak memahami masalah dengan benar sehingga tidak dapat menyususn rencana pemecahan. Ketidak sukaan siswa membaca masalah yang panjang dan bersifat non rutin juga menjadi salah satu alasan siswa salah dalam membuat rencana. Hasil ini memperkuat temuan Cruz dan Lapinid (2014) yang mengungkapkan bahwa kecerobohan, kurangnya pemahaman, perubahan nilai, dan kata-kata asing adalah beberapa kesulitan umum dihadapi oleh responden dalam menerjemahkan masalah soal cerita.

Tahap melaksanakan rencana penyelesaian yang dilakukan adalah menjalankan strategi yang telah dibuat dengan ketekunan dan ketelitian untuk mendapatkan penyelesaian. Kesalahan siswa dalam menyelesaikan soal pemecahan masalah matematis pada tahap memahami masalah sebesar $60,5 \%$. Pada tahap melaksanakan rencana penyelesaian, siswa melakukan kesalahan operasi pada perhitungan.

Tahap memeriksa kembali yang dilakukan adalah menafsirkan hasil yang diperoleh kedalam konteks masalah. Kesalahan siswa dalam menyelesaikan soal pemecahan masalah matematis pada tahap memeriksa kembali sebesar 86,8\%. Kesalahan yang dilakukan siswa adalah ketidakmampuan siswa dalam menafsirkan hasil yang diperoleh ke dalam konteks masalah dan memberikan argumennya. Hal ini dikarenakan siswa terbiasa membuat kesimpulan dan tidak terbiasa melakuakan tahap memeriksa kembali.

Penelitian diatas relevan dengan penelitian Tasyah et al (2015) menyatakan bahwa kesalahan siswa dalam menyelesaikan masalah meliputi kesalahan membaca dan memahami soal (reading error and reading comprehension difficultaty), kesalahan transformasi (transform error), kesalahan keterampilan proses (weakness in process skill), kesalahan dalam menggunakan notasi (encoding error). Hal tersebut juga sesuai dengan penelitian Phonapichat, Wongwanich, and Sujiva (2013) bahwa siswa memiliki kesulitan dalam memahami masalah matematika yang mempengaruhi proses penyelesaian masalah. Kesulitan siswa dalam pemecahan masalah yaitu 1) Siswa mengalami kesulitan dalam memahami kata kunci yang muncul, dengan demikian tidak dapat menafsirkannya dalam kalimat matematika. 2) Siswa tidak dapat menentukan apa yang harus dilakukan dan informasi apa dari masalah yang diperlukan untuk menyelesaikannya, 3) Siswa tidak memahami masalahnya, mereka cenderung menebak jawabannya tanpa proses berpikir, 4) Siswa tidak sabar dan tidak suka membaca masalah matematika, dan 5) Siswa tidak suka membaca masalah yang panjang.

\section{Analisis Self-Efficacy Siswa Pada Pembelajaran PBL}

Berdasarkan hasil penelitian yang diperoleh bahwa 38 siswa kelas VII-A, 2 siswa termasuk kategori yang memiliki self-efficacy sangat tinggi, 6 siswa termasuk kategori yang memiliki self-efficacy tinggi, 18 siswa termasuk kategori yang memiliki self-efficacy sedang, 
dan 12 siswa termasuk kategori yang memiliki selfefficacy rendah. Persentase keberadaan self-efficacy siswa berturut-turut adalah sangat tinggi 5,26\%, tinggi $15,79 \%$, sedang $47,37 \%$, dan rendah $31,58 \%$. Ini berarti keberadaan self-efficacy kategori sedang paling banyak dibandingkan kategori sangat tinggi, tinggi dan rendah. Hal ini juga sesuai dengan hasil evaluasi TIMSS 2011 dengan mengajukan 9 pernyataan dengan masing-masing empat alternatif jawaban diperoleh $34 \%$ siswa yang confident, $46 \%$ siswa somewhat confident, dan $21 \%$ siswa not confident.

Self-efficacy merupakan penentu yang mempengaruhi pilihan seseorang dalam upaya menghadapi kesulitan dan pola pikir serta reaksi emosional yang mereka alami (Sahendra, Budiarto, Fuad, 2018). Ketika seseorang rutin dengan tuntutan tugas atau kegiatan, mereka cenderung untuk memunculkan self-efficacy yang telah dikembangkan sebagai hasil dari pengalaman sebelumnya dengan tugas serupa. Hal tersebut sesuai dengan pendapat Engko (2008), pengalaman memiliki keberhasilan merupakan sumber self-efficacy terbesar karena didasarkan pada pengalaman pribadi yang telah dialami seseorang.

Bandura (2009) menyatakan bahwa kemampuan self-efficacy dapat memengaruhi pilihan aktivitas, usaha, dan ketekunan seseorang ketika memecahkan masalah. Hal di atas senada dengan pendapat Schunk dan Pajares (2002) menyatakan bahwa dengan selfefficacy yang tinggi, maka pada umumnya seorang siswa akan lebih mudah dan berhasil melampaui latihan-latihan yang diberikan padanya, sehingga hasil akhir dari pembelajaran tersebut yang tercermin dalam prestasi akademiknya juga cenderung akan lebih tinggi dibandingkan siswa yang memiliki self-efficacy lebih rendah.

Menurut Bandura (1997) yang menjadi dimensi dalam self-efficacy yaitu: dimensi magnitude, strength dan generality. Masing-masing dimensi memberikan implikasi penting bagi performen seseorang. Magnitude mengacu pada besarnya tingkat kesulitan tugas yang diyakini oleh seseorang untuk dapat diselesaikan. Strength mengacu pada kepercayaan yang ada dalam diri seseorang yang dapat diwujudkan untuk meraih performa tertentu. Generality mengacu pada keleluasaan dari self-efficacy yang dimiliki seseorang dapat diterapkan dalam situasi lain.

Berdasarkan hasil penelitian, pengelompokan siswa berdasarkan dimensi self-efficacy Bandura diperoleh bahwa: 1) Untuk dimensi Magnitude dengan tingkat self-efficacy sangat tinggi sebanyak 1 siswa, tingkat self-efficacy tinggi sebanyak 2 siswa, tingkat selfefficacy sedang sebanyak 6 siswa dan tingkat selfefficacy rendah sebanyak 4 siswa. 2) Untuk dimensi Streanght dengan tingkat self-efficacy tinggi sebanyak 2 siswa, tingkat self-efficacy sedang sebanyak 8 siswa, dan tingkat self-efficacy rendah sebanyak 7 siswa. 3) Untuk dimensi Generality dengan tingkat self-efficacy sangat tinggi sebanyak 1 siswa, tingkat self-efficacy tinggi sebanyak 2 siswa, tingkat self-efficacy sedang sebanyak 4 siswa, dan tingkat self-efficacy rendah sebanyak 1 siswa.
Siswa dengan self-efficacy dimensi magnitude dihadapkan pada tugas yang disusun menurut tingkat kesulitan tertentu maka kemampuan self-efficacy akan menuntunnya untuk mengerjakan tugas-tugas yang mudah, sedang, dan sulit sesuai dengan batas kemampuan yang dimilikinya untuk mencapai tujuan masing-masing tingkat tersebut. Indikator magnitude memiliki implikasi terhadap pemilihan tingkah laku mana yang harus dicoba atau mana yang akan dihindari. Siswa akan mencoba tingkah laku yang dirasa mampu dilakukan dan akan menghindari tingkah laku yang dirasa berada di luar batas kemampuannya. Siswa dengan self-efficacy dimensi strenght yang kuat maka akan pantang menyerah dan ulet dalam meningkatkan usahanya walaupun menghadapi rintangan. Sebaliknya, bila self-efficacy seseorang lemah maka akan cenderung mudah terguncang oleh hambatan kecil dalam menyelesaikan tugasnya. Siswa dengan self-efficacy dimensi generality ketika menyelesaikan masalah atau tugasnya, ada sebagian yang memiliki keyakinan yang terbatas pada suatu aktivitas dan situasi tertentu, sebagiannya lagi menyebar pada serangkaian aktivitas dan situasi yang bervariasi.

\section{KESIMPULAN}

Berdasarkan hasil analisis dan pembahasan dalam penelitian ini, dikemukakan beberapa simpulan sebagai berikut:

1. Siswa berkemampuan tinggi mampu melaksanakan tahapan Polya yaitu memahami masalah, membuat rencana penyelesaian, melaksanakan prosedur atau rencana dan memeriksa kembali. Siswa berkemampuan sedang mampu memahami masalah, membuat rencana penyelesaian, dan melaksanakan prosedur atau rencana yang telah dibuat. Siswa berkemampuan rendah hanya mampu memahami masalah pada tahapan Polya.

2. Kesalahan yang dilakukan siswa dalam menyelesaikan soal pemecahan masalah adalah tidak terdapat kesalahan pada tahap memahami masalah. Pada tahap membuat rencana penyelesaian, kesalahan terjadi dikarenakan ketidakmampuan mengkaitkan informasi satu dengan yang lainnya. Pada tahap melaksanakan rencana penyelesaian, kesalahan terjadi dikarenakan ketidak mampuan siswa untuk membuat rencana sehingga tidak mengerti cara menyelesaikan masalah dan terjadi kesalahan perhitungan pada proses penyelesaian. Pada tahap memeriksa kembali, kesalahan terjadi dikarenakan siswa tidak mampu menafsirkan hasil yang diperolehnya.

3. Siswa dengan self-efficacay dimensi magnitude berpandangan optimis dalam mengerjakan pelajaran dan tugas, membuat rencana dalam menyelesaikan tugas, memiliki jadwal belajar dan merasa yakin dalam menyelesaikan tugas. Siswa dengan selfefficacay dimensi strenght memiliki tujuan yang positif dalam melakukan berbagai hal, memiliki motivasi yang baik terhadap dirinya sendiri untuk pengembangan dirinya, gigih dalam menyelesaikan 
tugas, percaya diri terhadap kelebihan yang dimilikinya. Siswa dengan self-efficacay dimensi generality yang tinggi menjadikan pengalaman yang lalu sebagai jalan untuk mencapai kesuksesan, dapat menyikapi situasi yang berbeda dengan berpikiran positif, mampu mengatasi segala situasi dengan efektif, dan mau mencoba tantangan baru.

\section{REFERENSI}

Arends, R. I. 2012. Learning to Teach (Ninth Edition). New York: McGraw-Hill.

Bandura, A. 1977. Self-Efficacy: Toward a Uniflying Theory of Behavioral Change. Psychological Review. 84(2): 191-215.

1998. Self Efficacy. In H. Friedman (Ed) Encyclopedia of Mental Health. San Diego: Academis Press. 2009. Self-Efficacy in Changig Societies. Cambrige, UK: Cambridge University Press.

Bell, T. 1981. Promting Thinking Through Physical Education, Learning and Teaching in Action. 1: 3540.

Bern, R.G., Erickson, P. M. 2001. Contextual teaching and learning: preparing students for the new economy. Journal of Research no 5. Tersedia: http://www.cord.rg

Chrissanti, M. I., Widjajanti, D. B. 2015. Keefektifan Pendekatan Metakognitif Ditinjau dari Prestasi Bealajar, Kemampuan Berpikir Kritis, dan Minat Belajar Matematika. Jurnal Riset Pendidikan Matematika, 2(1): 51-62.

Cruz, J. K. B. Dela, \& Lapinid, M. R. C. 2014. Students' difficulties in translating worded problems into mathematical symbols. DLSU Research Congress 2014. Manila: De La Salle University. Tersedia: http://www.dlsu.edu.ph

Depdiknas. 2003. Undang-Undang No. 20 tahun 2003 Tentang Sistem Pendidikan Nasional. Jakarta: Depdiknas.

2006. Permendiknas Nomor 22 Tahun 2006 Tentang Standar Isi Sekolah Menengah Atas. Jakarta: Depdiknas.

Ersoy, E., \& Guner, P. (2015). The Place of Problem Solving and Mathematical Thinking in The Mathematical Teaching. The Online Journal of New Horizons in Education-January, 5(1).

Engko, C. 2008. Pengaruh Kepuasan Kerja Terhadap Kinerja Individual dengan Self Esteem dan Self Efficacy sebagai Variabel Intervening. Jurnal Bisnis dan Akuntansi, 10(1), 1-12.

Fitriani. 2012. Efektivitas Pembelajaran Matematika Dengan Menerapkan Problem-Based Learning Pada Siswa SMPN 4 Palopo. Jurnal Dinamika. 3(1): 32-39.

Fitriani, W. 2017. Analisis Self-Efficacy dan Hasil Belajar Matematika Siswa di MAN 2 Batusangkar Berdasarkan Gender. AGENDA. 1(1): 141-158.

Kemendikbud. 2013. Kerangka Dasar dan Struktur Kurikulum 2013. Jakarta: Kemendikbud.

Gagne, R. M. 1970. Learning Theory, Educational Media, and Individualized Instruction. ERIC. Tersedia: https://eric.ed.gov
Hasratuddin. 2018. Mengapa Harus Belajar Matematika?. Medan: Perc EDIRA.

Hung, Y. H., Chang, R. I., Lin, C. F. 2016. Hybrid learning style identification and developing adaptive problem-solving learning activities. Computers in Human Behavior.55: 552-561.

Litbang Kemendikbud. 2015. Survei Internasional TIMSS. Tersedia: http://litbang.kemdikbud.go.id

Lubis, J. N., Panjaitan, A., Surya, E., Syahputra E., 2017. Analysis Mathematical Problem Solving Skills of Student of the Grade VIII-2 Junior High School Bilah Hulu Labuhan Batu. International Journal of Novel Research in Education and Learning (Novelty Journals). 4(2): 131-137.

Moma, L. 2014. Peningkatan Self-Efficacy Matematis Siswa SMP Melalui Pembelajaran Generatif. Cakrawala Pendidikan. 33(3): 434-444.

Napitupulu, E. E. 2011. Pengaruh Pembelajaran Berbasis Masalah atas Kemampuan Penalaran dan Pemecahan Masalah Matematis Siswa Serta Sikap terhadap Matematika Siswa Sekolah Menengah Atas, Disertasi. SPs. UPI. Tidak dipublikasikan.

NCTM. 2000. Principles and standards for school mathematics. Reston, VA: NCTM.

OECD. 2013. PISA 2012 Results in Focus What 15year-olds know and what they can do with what they know. Tersedia: http://www.oecd.org

Phonapichat, P., Wongwanich, S., Sujiva, S. 2013. An analysis of elementary school students' difficulties in mathematical problem solving. World Conference on Education Science (WCES 2013 Procedia Social and Behavior Science. 8116 (2014) 3169-3174.

Polya, G. 1973. How to Solve It. Second Edition. Princeton University Press.

Rianti, R. 2018. Profil Kemampuan Pemecahan Masalah Matematis Siswa SMP Pada Materi Bangun Ruang Sisis Datar. Jurnal Pendidikan Tembusai. 2(4): 802-812.

Sahendra, A., Budiarto, M.T., \& Fuad, Y. 2018. Students' Representation in Mathematical Word Problem-Solving: Exploring Students' Selfefficacy. Journal of Physics: Conference Series, Ser. 947012059.

Saparwadi, L., Cahyowatin. (2018). Proses Pemecahan Masalah Matematika Siswa Berkemampuan Tinggi Berdasarkan Langkah Polya. UNION: Jurnal Pendidikan Matematika. 6(1): 99-110.

Schoenfeld, A.H. (2016). 100 Years of curriculum history, theory, and research. Educational Researcher, 45(2), 105-111.

Schunk, D.H., \& Pajares, F. (2002). The Development of Academic Self-Efficacy. San Diego: Academic Press.

Sunaryo, Y. 2017. Pengukuran Self-Efficacy Dalam Pembelajaran Matematika di MTs N 2 Ciamis. Jurnal Teori dan Riset Matematika (TEOREMA). 1(2): $39-44$

TIMSS. 2011. TIMSS 2011 International Result In Mathematics. Chestnut Hill: TIMSS dan PIRLS International Study Center. Tersedia: http://timssandpirls.bc.edu 